\title{
Trinitarian Hagiography in Late Medieval England: Rewriting St Robert of Knaresborough in Latin Verse
}

\author{
Hazel J. Hunter Blair* \\ University of Lausanne
}

\begin{abstract}
The Order of the Holy Trinity for the Redemption of Captives (or Trinitarian Order) is one of the least studied continental religious groups to have expanded into thirteenth-century England. This article examines shifting notions of Trinitarian redemption in late medieval England through the prism of the order's writing about Yorkshire hermit St Robert of Knaresborough (d. 1218). Against the Weberian theory of the routinization of charisma, it demonstrates that Robert's inspirational sanctity was never bound too rigidly by his Trinitarian hagiographers, who rather co-opted his unstable charisma in distinct yet complementary ways to facilitate institutional reinvention and spiritual flourishing in the fourteenth and fifteenth centuries.
\end{abstract}

Recent scholarship on late medieval cultural institutions has shown an increased interest in a diversity of religious orders. Once seen as belonging to an era of monastic decline, following a 'golden age' of twelfth- and thirteenth-century expansion, late medieval English religious houses have been reframed by modern scholars as sites of intellectual and spiritual vitality and creativity. ${ }^{1}$ Rarely, however,

* Section of English, Faculty of Letters, Bâtiment Anthropole, University of Lausanne, CH-1015 Lausanne-Chamberonne, Switzerland. E-mail: hazel.blair@unil.ch. Thank you to Christiania Whitehead, Denis Renevey, Alasdair Grant, John Jenkins, Robin Hughes and the editors and reviewers for their suggested revisions, and to Alasdair for correcting my Latin and transcriptions (any errors remain my own). This research was funded by the Swiss National Science Foundation (project no. 100015_166133) and was presented in 2019 at the conference 'Northern Lights: Late Medieval Devotion to Saints from the North of England' (Lausanne), the Leeds International Medieval Congress and the Summer Conference of the Ecclesiastical History Society (Durham).

1 See, for example, James G. Clark, ed., The Religious Orders in Pre-Reformation England (Woodbridge, 2002); Janet Burton and Karen Stöber, eds, Monasteries and Society in the British Isles in the Later Middle Ages (Woodbridge, 2008).

Studies in Church History 57 (2021), 74-95 (C) The Author(s), 2021. Published by Cambridge University Press on behalf of Ecclesiastical History Society. This is an Open Access article, distributed under the terms of the Creative Commons Attribution-NonCommercialNoDerivatives licence (http://creativecommons.org/licenses/by-nc-nd/4.0/), which permits non-commercial re-use, distribution, and reproduction in any medium, provided the original work is unaltered and is properly cited. The written permission of Cambridge University Press must be obtained for commercial re-use or in order to create a derivative work.

doi: $10.1017 /$ stc. 2021.5 
has the English history of the Order of the Holy Trinity for the Redemption of Captives (hereafter: the 'Trinitarian Order' or 'Trinitarians') received sustained academic focus. ${ }^{2}$ Where the order's English province has been made a subject of academic enquiry, archaeological and antiquarian writers have focused on the establishment of individual foundations or on their roles as hospitals. ${ }^{3}$ Without a full history of the order to refer to, it is unsurprising that modern scholarship has often perpetuated narratives of English Trinitarian unlearnedness, obscurity and decline following the Black Death. ${ }^{4}$ Nevertheless, Karen Stöber has noted that the order was 'popular with lay patrons and benefactors' in late medieval England, while R. N. Swanson has drawn attention to industrious Trinitarian engagement with the fourteenth- and fifteenth-century indulgence trade, suggesting that there is yet more to uncover about the nature of English Trinitarian life. ${ }^{5}$

2 Starting points for Trinitarian history include Giulio Cipollone, Cristianità-Islam. Cattività e liberazione in nome di Dio. Il tempo di Innocenzo III dopo 'il 1187', Miscellanea Historiae Pontificiae 60 (Rome, 1992); James W. Brodman, Charity and Religion in Medieval Europe (Washington DC, 2009), 150-62; Yvonne Friedman, Encounter between Enemies: Captivity and Ransom in the Latin Kingdom of Jerusalem (Leiden, 2002), 189-206.

3 Nicholas Orme, 'Warland Hospital, Totnes and the Trinitarian Friars in Devon', Devon and Cornwall Notes and Queries 36 (1987), 41-8; Margaret Gray, The Trinitarian Order in England: Excavations at Thelsford Priory, ed. Lorna Watts and Phillip Rahtz, British Archaeological Reports, British Series 226 (Oxford, 1993); Neil R. Aldridge, 'The Trinitarian Priory of Motynden at Headcorn', Archaeologia Cantiana 115 (1995), 177212; Tim Pestell, 'Of Founders and Faith: The Establishment of the Trinitarian Priory at Ingham, Norfolk (England)', in Guy de Boe and Frans Verhaeghe, eds, Papers of the Medieval Europe Brugge 1997' Conference, 6: Religion and Belief in Medieval Europe (Zellik, 1997), 65-78.

4 Paul Deslandres said the English Trinitarians 'played no role in the order', due to their 'isolated situation': L'Ordre des Trinitaires pour le Rachat des Captifs, 2 vols (Paris, 1903), 1: 187 (translation mine). The English Trinitarians were dubbed 'a small and unlearned order' by John B. Friedman, 'The Cipher Alphabet of John de Foxton's Liber Cosmographic', Scriptorium 36 (1982), 219-35, at 234. It has been suggested that in England, '[f]or the Trinitarians in general, the later fourteenth and fifteenth centuries were a time of decline and even of crisis': Orme, 'Warland Hospital', 44; cf. Gray, Trinitarian Order in England, 14. The Trinitarians are termed 'marginal' and 'not particularly favoured in England' in Brodman, Charity and Religion, 158; and 'obscure' in Richard W. Pfaff, The Liturgy in Medieval England: A History (Cambridge, 2009), 383. There is a sense that there may be too few written sources to support English Trinitarian history: Charles Cornish-Dale, “"A Pint of these Maiden Cuthburga Oats": The Cult of St Cuthburga at Thelsford Priory, Warwickshire, October 1538', Midland History 42 (2017), 183-93, at 184.

5 Karen Stöber, Late Medieval Monasteries and their Patrons: England and Wales, c. 1300 1540 (Woodbridge, 2007), 13, 52-3; R. N. Swanson, Indulgences in Late Medieval England: Passports to Paradise (Cambridge, 2007), especially 63-4. 
This article highlights developments in the literary and spiritual lives of late fourteenth- and fifteenth-century English Trinitarians, concentrating on Trinitarian writing about Yorkshire hermit St Robert Flower (d. 1218), patron saint of the order's priory at Knaresborough (founded c.1252). ${ }^{6}$ It makes comparative reference to all extant lives of Robert (three of which are Trinitarian and one of which may be Cistercian), but is focused on analysing the Trinitarian Latin verse life, the anonymous De nobilitate vite Sancti Roberti confess[oris] (hereafter: De nobilitate). ${ }^{7}$ This text deviates from other narratives of Robert's sanctity, which centred on his supreme charity, but despite this distinctiveness it remains the least referenced of the Trinitarian hagiographies, all of which are preserved in a single manuscript in the British Library, MS Egerton $3143 .{ }^{8}$ Examining the Latin verse life in its manuscript, literary and historical contexts, the article delineates a key contradiction in the way Robert's inspirational charisma was institutionalized and memorialized by later medieval Trinitarians, arguing that this can be resolved by observing that Robert's late medieval hagiographers wrote to inspire different groups of his devotees in distinct yet complementary ways.

${ }^{6}$ CPReg, 1: 1198-1304, 277. On Robert, see Brian Golding, 'The Hermit and the Hunter', in John Blair and Brian Golding, eds, The Cloister and the World: Essays in Medieval History in Honour of Barbara Harvey (Oxford, 1996), 95-117; Joshua Easterling, 'A Norbert for England: Holy Trinity and the Invention of Robert of Knaresborough', Journal of Medieval Monastic Studies 2 (2013), 75-107; Ralph Hanna, "'So to interpose a little ease": Northern Hermit-lit', in Anita Auer et al., eds, Revisiting the Medieval North of England: Interdisciplinary Approaches (Cardiff, 2019), 73-90; Laura Slater, 'Recreating the Judean Hills? English Hermits and the Holy Land', JMedH 42 (2016), 603-26; Tom Licence, Hermits and Recluses in English Society, 950-1200 (Oxford, 2011), 173-6; Christopher Holdsworth, 'Hermits and the Powers of the Frontier', Reading Medieval Studies 16 (1990), 55-76.

7 Two Latin prose lives of St Robert (one of which is Trinitarian) are edited in Paul Grosjean, 'Vitae S. Roberti Knaresburgensis', Analecta Bollandiana 57 (1939), 364400. These are partly reproduced, alongside Middle English and Latin verse versions of Robert's legend (both of which are Trinitarian), in Joyce Bazire, ed., The Metrical Life of St Robert of Knaresborough; Together with the other Middle English Pieces in British Museum Ms. Egerton 3143, EETS 228 (London, 1968). ET of the Trinitarian prose life in Frank Bottomley, trans., St Robert of Knaresborough (Ilkley, 1993). All translations from De Nobilitate (in Bazire, ed., Metrical Life, Appendix C, 134-44) are my own.

8 Easterling discusses Robert's Trinitarian hagiography (Latin prose and Middle English) in 'A Norbert for England', examining the Latin verse life briefly in 'Singulare Propositum: Hermits, Anchorites and Regulatory Writings in Late Medieval England' (PhD thesis, Ohio State University, 2011), 136. 


\section{Adopting THe CulT}

The Trinitarian Order was founded in 1198 in northern France by one John, variously called 'de Matha' and 'de Provence' by medieval writers. Active in the diocese of Meaux, he first appears in the documentary record as head of a religious foundation at Cerfroid. This house was primarily committed to the redemption of Christians held captive by 'enemies of the cross', and Innocent III granted it his protection by papal bull in May $1198 .{ }^{9}$ Innocent issued another letter that December, describing John as the driving force behind the new Order of the Holy Trinity, which was established to pursue the release of Christians imprisoned for their faith while on crusade. ${ }^{10}$ The Trinitarian Rule, appended to Innocent's December letter, stated that this was an activity for which one third of the order's income should be reserved, the other two thirds being earmarked for local poor relief and for the maintenance of the brothers. ${ }^{11}$ The new order, which was committed to poverty, charity and redemption, first expanded into southern France and Spain, but came to establish houses across medieval Christendom, including ten in England.

The Trinitarians penned at least three versions of Robert Flower of Knaresborough's life in the Middle Ages (one in Latin prose, one in Latin verse, and one in Middle English verse), all of which are preserved in single copies, alongside histories of the Trinitarian Order and further devotional materials pertaining to Robert, in a late fifteenth-century manuscript from Knaresborough Priory, MS Egerton 3143. Despite this juxtaposition of material, Robert was not a Trinitarian himself. There is a dearth of evidence relating to Robert and dating from his lifetime, but his eremitism is confirmed in a royal grant: in February 1216, King John issued a letter to his Brian de L'Isle, Constable of Knaresborough in the West Riding of Yorkshire, instructing him to confer half a carucate of woodland upon 'brother Robert the Hermit', as close as possible to his hermitage

9 'Cum a nobis petitur', 16 May 1198; edited in Cipollone, Cristianità-Islam, 489 (no. 18; quoted in translation in Friedman, Encounter between Enemies, 189).

10 'Operante divine dispositionis', 17 December 1198; edited in O. Hageneder et al., Die Register Innocenz' III., 1/1: Pontifikatsjahr 1198/99 (Graz and Cologne, 1964), 703 (no. 481; translated in Anthony O. D'Errico, The Trinitarians: An Overview of their Eight Hundred Year Service to God and Humanity [Rome, 2002], 54-62).

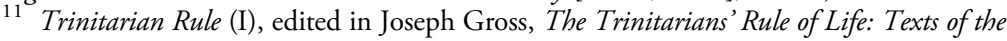
Six Principal Editions (Rome, 1983), 9-15 (ET online at <http://www.trinitari.org/ Inglese/L'ordine/Costituzioni\%20-\%20Regola.html>, accessed 7 September 2019). 
(hermitago). ${ }^{12}$ No further documentary references to Robert survive from his lifetime and he left no writings to posterity. Yet this grant suggests that he was an independent actor in the eremitic revival of the High Middle Ages, embraced elsewhere institutionally by Cistercians, Carthusians and other reformers who sought comparable returns to Christianity's desert roots. ${ }^{13}$

Nevertheless, Robert seems to have been dissatisfied with contemporary clerical and monastic institutions. According to his hagiographers, he was born in York and began an ecclesiastical career before entering the Cistercian abbey of Newminster, in Northumberland. Excelling there spiritually, he departed and took up residence with a Knaresborough hermit who later abandoned him. After a year alone mortifying his flesh in a chapel dedicated to St Hilda of Whitby, Robert moved to Spofforth, where his zealous devotions gave rise to rumours of his extraordinary holiness. Crowds gathered to praise him, causing the holy man, fearful of vanity, to flee and take up residence with the Benedictines at Headley Priory. Rejected by them on account of his austere way of life, however, Robert returned to the wilderness and St Hilda's chapel. Here he engaged in devotional activity while managing a small eremitic community consisting of four servants dedicated to agricultural work and poor relief. Despite these meritorious works, Robert found himself fending off demonic attacks and resisting the persecutions of landowner William de Stuteville. In the end, William's men destroyed his hermitage, and Robert fled to a new site: a cave on the northern bank of the River Nidd by Knaresborough. His brother Walter financed the building of a chapel adjoined to this new hermitage, where Robert continued to attract a following on account of his devotions, miracles, prophecies and charitable activities. Here, Robert caught the attention of King John, in whose presence the saint brazenly demonstrated the limits of royal authority. The Cistercians at nearby Fountains Abbey, impressed by his sanctity, tried to recruit Robert into their community and, later, to inter him at their monastery. Both attempts failed, and Robert was buried in his hermitage upon his death in

\footnotetext{
12 Rotuli litterarum clausarum in Turri Londinensi asservati, ed. Thomas Duffus Hardy, 2 vols (London, 1833-4), 1: 249.

13 Henrietta Leyser, Hermits and the New Monasticism: A Study of Religious Communities in Western Europe, 1000-1150 (New York, 1984); Gert Mellville, The World of Medieval Monasticism: Its History and Forms of Life, trans. James D. Mixon (Collegeville, MN, 2016), especially 89-124, 'Return to the Desert'; Licence, Hermits and Recluses.
} 
1218. The cave-chapel became a site of pilgrimage, although Robert's relics were later translated to the nearby Trinitarian priory of Knaresborough, which inherited the site in the middle of the thirteenth century, along with all the land King John had given to Robert during his lifetime. ${ }^{14}$ Henceforth, Robert's cult was managed by the Knaresborough Trinitarians, who adopted him as their spiritual patron.

In many ways, Robert was not an obvious candidate for Trinitarian veneration: he did not found any Trinitarian houses and does not appear to have had contact with the order during his lifetime. Unlike his eremitic predecessor St Godric, he did not venture abroad to areas of Trinitarian interest such as the Holy Land or the Iberian peninsula. Nor was he famed for releasing captives or working other liberation miracles, like St Foy or (more locally) St Cuthbert. Moreover, whilst the majority of Robert's extant cult literature bears marks of Trinitarian authorship, the Trinitarians were not the first order to venerate him: a fragmentary version of Robert's life is preserved in British Library MS Harley 3775 and was perhaps authored by the Cistercians. ${ }^{15}$ It is not within the scope of this article to provide a full analysis of Cistercian influence on the development of Robert's hagiographic persona, but the most distinctive aspect of the hermit's sanctity according to this early text was his charity: the nature (substancia) of this saintly or holy man (sancti viri) is defined in the prologue in relation to his tendency to extend his generosity towards the poor (manus largas extendendo pauperibus). ${ }^{16}$ The same text also focuses on Robert's eremitism, not only in its title (Vita sancti Roberti heremite), but also through depicting him heroically as a soldier (miles) and athlete (athleta) of Christ who dwelt in the wilderness (heremo) amid numerous persecutions, some of them self-inflicted. ${ }^{17}$ It seems plausible that the Cistercians penned this life while seeking acquisition of Robert's relics or hermitage, and that in so doing they emphasized elements of his spirituality with

\footnotetext{
14 William Dugdale, Monasticon Anglicanum: A New Edition, ed. John Caley, Henry Ellis and Bulkeley Bandinel, vol. 8 (London, 1846), 1566 (no. II).

15 Vita sancti Roberti heremite [hereafter: VA], ed. Grosjean, 365-74 (all translations mine); Licence, Hermits and Recluses, 193-4.

${ }^{16}$ VA 1 (ed. Grosjean, 367). Robert is also said to have stored food for the poor: ibid. 5 (ed. Grosjean, 369).

17 Ibid. 1, 3, 5 (ed. Grosjean, 366, 368, 369).
} 
which their order empathized most, particularly his desert spirituality. ${ }^{18}$

Robert's charitable reputation as recorded in this early life was embraced by his first Trinitarian hagiographer. This is particularly pertinent, considering that northern European Trinitarians were rarely involved in active ransom missions, instead performing other good works while supporting their order's titular redemptive cause financially, via alms-collecting. ${ }^{19}$ Indeed, although royal protections were granted to English members of the 'Order of the Holy Trinity and the Ransom of Captives of the Holy Land' so that they might collect alms 'for the ransom of such captives', early English Trinitarians are more commonly recognized as having cared primarily for the local poor and sick and those who visited their hospitals. ${ }^{20}$ Robert's shrine surely attracted many such individuals to Knaresborough, and so it is perhaps unsurprising to find that when writing about him the Trinitarians elaborated upon his charitable tendencies: the Trinitarian author of the saint's prose life in the Egerton manuscript implies Robert's direct involvement with the collection of alms for poor relief, for example, whereas the Harley vita suggests that Robert delegated alms-collecting to one of his servants, distancing the saint somewhat from day-to-day charity work despite his generous spirit. ${ }^{21}$ Thus, while comparison of the two vitae is limited by the fragmentary state of the Harley text, Robert's work on behalf of the poor is emphasized in the Trinitarian prose vita, which, as Joshua Easterling has demonstrated, simultaneously presents the hermit as a devotee of the Trinity and (through clever rhetoric and compilation) as a natural spiritual patron and point of origin for the Trinitarian community at Knaresborough. ${ }^{22}$

\footnotetext{
18 Tom Licence, 'The Benedictines, the Cistercians and the Acquisition of a Hermitages in Twelfth-Century Durham', JMedH 29 (2003), 315-29.

19 James Brodman, 'Trinitarian and Mercedarian Orders: A Study of Religious Redemptionism in the Thirteenth Century' (PhD thesis, University of Virginia, 1974), 157. 20 Calendar of the Patent Rolls preserved in the Public Record Office of Great Britain: Edward I, 3: 1292-1301 (London, 1897), 253 (issued 18 June 1297). Similar references can be found in royal correspondence covering the period 1242-1336. On account of their charitable activity, Brodman groups the Trinitarians under 'The Hospitaller Orders': Charity and Religion, 126-77.

21 Vita Sancti Roberti iuxta Knaresburgum [hereafter: VR] 6 (ed. Grosjean, 375-400, at 381); cf. VA 6 (ed. Grosjean, 372).

22 Easterling, 'A Norbert for England', 75-107. As Easterling notes, the dating of this text is uncertain: ibid. 77 n. 9. Holdsworth, 'Hermits and the Powers of the Frontier', 73
} 
The literary strategies that Easterling argues the Trinitarian prose hagiographer used to legitimize Knaresborough Priory's connection to its patron saint might usefully be articulated by analogy with what Max Weber called the 'routinization of charisma', summarized as 'a process through which the enthusiasm generated by the prophet and his followers might be channelled into the foundation of a community or religious order'. ${ }^{23}$ Robert's charisma is suggested by his miracles and the excitement his sanctity inspired in his contemporaries, but also by his rejection of contemporary church institutions and monastic rules, coupled with his disdain for secular authority, which reflects Weber's observation that charismatics are inherently disruptive figures. According to Weber, charisma is both transitory and unstable, such that attempts to grant it permanence necessarily result in changes to its nature which diminish the purity of its nascent form. When charismatic authority is routinized by an institution, then, it loses some of its unruly potency, becoming 'a component of a concrete historical structure'. ${ }^{24}$ Thus the Harley vita emphasizes the eremitic tradition to which Robert belongs, which would certainly have been of interest to a Cistercian audience ideologically invested in that same lineage, while the Trinitarian prose hagiographer chooses to emphasize Robert's entrepreneurial spirit and active charity at the expense of his eremitic purity. As C. Stephen Jaeger has observed, however, texts (and especially hagiographies) can themselves 'exercise charismatic effects', spurring devoted readers past simple admiration for their subjects and on to imitation. ${ }^{25}$ Indeed, Robert's Trinitarian prose hagiographer arguably 'textualizes' his charisma (to borrow Jaeger's terminology) in such a way as to preserve the energetic momentum of its nascent instability: as Easterling argues, the text

n. 12, suggests the mid-thirteenth century, which would accord with the earliest known reference to Knaresborough Priory as the house 'of St Robert' (see n. 6 above), and with Easterling's reading of the $V R$ as a text focused on constructing pater Robertus.

23 Andrew Brown, 'Charisma and Routine: Shaping the Memory of Brother Richard and Joan of Arc', Religions 3 (2012), 1162-79, at 1164; Max Weber, Economy and Society: An Outline of Interpretative Sociology, ed. Guenther Roth and Claus Wittich, 2 vols (Berkeley, CA, 1978), 2: 1111-57.

24 Weber, Economy and Society, 2: 1121.

25 C. Stephen Jaeger, 'The Saint's Life as Charismatic Form: Bernard of Clairvaux and Francis of Assisi', in Brigitte Miriam Bedos-Rezak and Martha Dana Rust, eds, Faces of Charisma: Image, Text, Object in Byzantium and the Medieval West (Boston, MA, 2018), 181-204, at 175-6. 
encourages readers to imagine Robert in 'elastic and indeterminate' ways, respecting local history and literary tradition by never quite labelling Robert a Trinitarian founder while nevertheless engaging 'the powers of uncertainty' in order to imply Robert's authority as Knaresborough Priory's spiritual initiator. ${ }^{26}$ Therefore, while the Trinitarian prose vita routinizes Robert's charisma to some extent, it also embodies that charisma in such a way as to encourage wishful thinking on the part of Trinitarian readers and to inspire them to action in Robert's image. ${ }^{27}$

Nevertheless, while Trinitarian institutionalization of Robert's charisma in the thirteenth century depended on clever crafting of Robert's life, it was also necessarily predicated upon securing a stable connection between Robert's holy reputation and the wider Trinitarian mission. ${ }^{28}$ Indeed, Robert's alms-collecting and care for the poor retained a key place in Trinitarian expressions of his sanctity into the later Middle Ages: the Middle English translation of Robert's life (MS Egerton 3143, fols 39v-60v), produced around the turn of the fifteenth century, thus makes frequent reference to Robert's charitable concerns, even emphasizing that the saint's principal purpose was 'to begge an brynge pore men of baile'. ${ }^{29}$ It is striking, then, that the Trinitarian author of Robert's life in Latin verse minimizes this aspect of the hermit's sanctity in his rewriting of the saint's legend: indeed, based on the Latin verse text alone one would never suspect that Robert had once been renowned for alleviating poverty. ${ }^{30}$ How should we explain this radical departure from the established narrative of Robert's holiness and its juxtaposition with competing images of his sanctity in a late medieval Trinitarian manuscript?

\section{De nobilitate: St Robert in Latin Verse}

Robert's Latin verse life is an alliterative poem in 116 stanzas of four lines each with rhyming pattern aab cccb; it is the first item in the

\footnotetext{
26 Easterling, 'A Norbert for England', 104-5, 84.

27 'It appears as though certain brothers at Knaresborough wished to believe him their order's founding hermit': ibid. 105.

28 The Trinitarian prose hagiographer 'finds in Robert an author of Trinitarian ideals': ibid. 93.

29 Bazire, ed., Metrical Life, line 295.

30 Robert's charity is implied only once in De nobilitate (stanza 41), where the hagiographer references the hermit's 'destitute' (egenis) guests.
} 
Egerton manuscript, where it is followed immediately by an account of the foundation of the Trinitarian Order, De innovatione Ordinis Sancte Trinitatis (hereafter: De innovatione). ${ }^{31}$ This second text is also in Latin verse and has a rhyme scheme identical to the hagiography preceding it. The two texts are distinct, and yet they are a pair, bound together materially, metrically and linguistically in the form of a textual diptych. They have not been dated formally, but may have been produced in the fourteenth or fifteenth centuries: A. G. Rigg has dated a similar textual pairing concerning another Yorkshire saint (a Latin verse life of St Hilda of Whitby, which survives coupled with a Latin verse account of the refoundation of Whitby Abbey) to this period. ${ }^{32}$ Indeed, as Rigg has noted more generally, the fourteenth and fifteenth centuries witnessed 'a rise in literary interest in Northern saints and antiquities', with the production of a Latin metrical chronicle of the church of York in the late fourteenth century, as well as composition of a Latin verse poem on the archbishops of York to 1455 , and further fifteenth-century Latin poetry sanctifying Richard Scrope, archbishop of York (d. 1405). ${ }^{33}$ Given the form and Yorkshire provenance of the Latin verse diptych in the Egerton manuscript, it would not be unreasonable to suggest that the Latin verse hagiography and its attached history were written at around the same time, so that the pairing might be dated, roughly, to the late fourteenth or fifteenth centuries. Indeed, as demonstrated below, the decision to rework Robert's life in Latin verse might fruitfully be read in relation to institutional and spiritual changes taking place in the English Trinitarian province at around this time.

By comparison with the Trinitarian prose and Middle English texts, Robert's verse vita is a reshuffled and heavily edited version of his life story. ${ }^{34}$ The text is front-loaded with lengthy descriptions of the saint's eremitism, labelling Robert a hermit from the moment he is introduced in the sixth stanza. ${ }^{35}$ The Trinitarian prose hagiographer, by contrast, took care to stress Robert's institutional ties and,

31 In Bazire, ed., Metrical Life, Appendix D, 144-8.

32 A. G. Rigg, 'A Latin Poem on St Hilda and Whitby Abbey', Journal of Medieval Latin 6 (1996), 12-43.

33 A. G. Rigg, A History of Anglo-Latin Literature, 1066-1422 (Cambridge, 1992), 293-4, 311.

34 Bazire, ed., Metrical Life, Introduction, 33.

35 De nobilitate, stanza 6. 
long before narrating the saint's eremitic turn, informed readers that Robert:

... was in the habit of frequenting churches and even more often spending time in monasteries and the chosen youth [electus adolescens] had the intention of serving God more fervently in the office of the priesthood. I am totally ignorant of what made him withdraw from this initial intention. ... Anyway, this devout man, turning to the bishop, persistently asked for ordination to the subdiaconate and the bishop willingly agreed to his request. However, when he had been raised to this minor order by the hand of the bishop, he withdrew from proceeding to major orders. ${ }^{36}$

The Middle English Life does feature an early celebration of Robert's eremitism (lines 17-24) but nevertheless emphasizes his youthful ties to schools ('scoles', line 77), the priesthood (line 90) and the subdiaconate (line 92). Indeed, where the Life and the Trinitarian prose hagiography present readers with an images of a young churchgoer keen on an ecclesiastical career, the Latin verse text omits much of this information, instead covering Robert's parentage and background briefly, before narrating his embrace of the wilderness:

Domus dapis declinavit, Knaresburgo festinavit, Ibi carnem conculcavit Miris [ab]stinenciis.

Adherebat heremite Valde virtuose vite, Latitanti sine lite, Presso penitenciis.

Inspiratus sponte sprevit Voluptatis facta; flevit, Et sub rupe requievit

Fretus in foramine.

36 VR 1 (ed. Grosjean, 378; Bottomley, trans., St Robert of Knaresborough, 3). 
Hic Robertus residebat,

Dum prodire proponebat

Herimata quem habebat

Secum pro solamine. ${ }^{37}$

Similarly, further episodes from the Trinitarian prose and Middle English texts in which Robert experiments with monasticism at Newminster and Headley are reduced to only a stanza or two in Latin verse. ${ }^{38}$ Robert's initial journey into the wilderness is elaborated in the Latin verse before either of these monastic episodes is related, and Robert also seems lonelier: we learn little of his earliest eremitic companion and nothing of the four assistants at his early community at $\mathrm{St}$ Hilda's. ${ }^{39}$ Thus, by comparison with the Trinitarian prose and Middle English lives, which stress the saint's care for the poor and his ties to the established church, the monastic, institutional and charitable moments in Robert's life are diminished in the Latin verse. What remains is an image of Robert in which his sanctity seems predicated on asceticism and devotional activity, rather than on ecclesiastical community-building or care for the poor. But to what extent was this extra-institutional and prayerful eremitism of interest to a community like the Trinitarians, who had once written to bind their patron saint's reputation for charity to their corporate emphasis on active works of mercy in honour of the Trinity?

As François Dolbeau has demonstrated, Latin verse vitae in devotional manuscript contexts were often produced as aids to meditation and individual piety. ${ }^{40}$ From much of the secondary literature, however, one gets the impression that the English Trinitarians were unlearned, practical men, and that, moving into the later Middle

\footnotetext{
37 'Declining household feasts, he hurried to Knaresborough where he spurned meat with remarkable abstinence. He adhered vigorously to the virtuous life of a hermit, secluded without smear, suffering self-inflicted penitence. Inspired [by God], he voluntarily scorned deeds of pleasure; he wept and rested beneath the cliff, protected by a cave. Here Robert lived until the hermit whom he had with him for comfort proposed to leave': De nobilitate, stanzas 13-16. Robert's ordination as subdeacon is referred to in passing in stanza 17.

$38^{\circ}$ Newminster: ibid., stanza 18, cf. VR 2 (ed. Grosjean, 378-9); Life, lines 97-126. Headley: De nobilitate, stanzas 23-4; cf. VR 5 (ed. Grosjean, 380-1); Life, lines 215-38. 39 See VR 2 (ed. Grosjean, 378-9); Life, lines 134-72, where details of Robert's initial embrace of the wilderness near Knaresborough follow the narration of his entry into Newminster.

40 François Dolbeau, 'Un Domaine négligé de la littérature médiolatine. Les Textes hagiographiques en vers', Cahiers de Civilisation Médiévale 45 (2002), 129-39, at 134.
} 
Ages, the English province was in decline; that it struggled financially to operate its hospitals, the Black Death having been felt acutely by the Trinitarians due to their relatively small number in England by comparison with better established religious orders. ${ }^{41}$ Nevertheless, as Carole Rawcliffe and others have highlighted, medieval hospitals (unlike their modern equivalents) were essentially religious houses, 'chiefly concerned with the promotion of spiritual rather than physical health', and they frequently facilitated liturgical, devotional and meditative activity, perhaps even more so in the period after the Black Death, when financial difficulties meant that the survival of hospitals depended on their ability to minister to the spiritual health of patrons and their deceased relatives. ${ }^{42}$ Thus there is a degree of contradiction in the literature pertaining to Trinitarian life in England. It is true that in 1402 the English Trinitarian province stated that it could not afford to contribute the 'ransoming third' of its income towards the order's founding goal of the redemption of captives, instead petitioning for continued payment of a smaller quota. ${ }^{43}$ In particular, during the period after 1350, financial and staffing difficulties seem to have affected the Trinitarians in Oxford, Hertford, Easton and Totnes. ${ }^{44}$ But to view this period as one of general decline for the English Trinitarians, or as a period in which they had drifted away from their order's founding redemptive purpose, does not do justice to the complexity of the institutional transformations taking place in the late medieval English province.

As W. G. Clark-Maxwell and R. N. Swanson have shown, among the religious orders of late medieval England, the Trinitarians were some of the most prolific producers of letters of confraternity in the fifteenth century. ${ }^{45}$ Examples of these documents survive from Knaresborough, Hounslow, Mottenden, Ingham, Thelsford and

41 See n. 4 above.

42 Carole Rawcliffe, Medicine for the Soul: The Life, Death and Resurrection of an English Medieval Hospital, St Giles's, Norwich, c.1249-1550 (Thrupp, 1999), 103-8; Nicholas Orme and Margaret Webster, The English Hospital, 1070-1570 (New Haven, CT, 1995), 49, 139.

43 Lateran Regesta 109 (1402-3), in CPReg, 5: 1398-1404, 543-57, online at: British History Online, <http://www.british-history.ac.uk/cal-papal-registers/brit-ie/vol5/ pp543-557>, accessed 10 September 2019; Brodman, Charity and Religion, 158; idem,

'Trinitarian and Mercedarian Orders', 239.

44 Orme, 'Warland Hospital', 44.

45 [William Gilchrist] Clark-Maxwell, 'Some further Letters of Fraternity', Archaeologia 79 (1929), 179-216, at 192-3; see also n. 5 above. 
Walknoll. They certified the extension of spiritual privileges to lay associates of the order in return for financial patronage. Trinitarian letters generally offered the recipient remittance of several years' penitential punishment, thereby reducing the amount of time the recipient would spend in purgatory, alongside the privilege of choosing a deathbed confessor capable of granting plenary remission of sins and particular burial privileges, while also promising the holder posthumous prayers for their soul on a par with those offered to full members of the order. ${ }^{46}$ Reading these sources from a post-Reformation standpoint or in the context of anti-fraternal sentiment, one might be tempted to view later Trinitarians as desperate pedlars of spurious promises, but as Robert W. Shaffern and others have stressed, the image of the corrupt pardoner has been frequently exaggerated, both in the medieval sources themselves and in modern historiography. ${ }^{47}$ While there certainly was a financial aspect to Trinitarian confraternity, the order was plainly invested in late medieval England's spiritual economy, and arguably interested less in crude fundraising than in stimulating and rewarding lay charity. ${ }^{48}$ Moreover, drawing on the theory of 'cultural capital' outlined by sociologist Pierre Bourdieu, Nicole R. Rice has emphasized that laypeople in late medieval England treated letters of confraternity as a means by which they might 'accrue spiritual capital'. ${ }^{49}$ Spiritual capital, like cultural capital, can exist in many forms, and thus in procuring letters of confraternity (the objectified form), the laity could, by way of association, benefit from (and thereby embody) some of the institutional spiritual capital that had been produced and conserved by the house and order issuing the letters. ${ }^{50}$ The relatively high number of surviving English Trinitarian letters may therefore imply that the brethren were famed and valued in England not only for their redemptive crusading

46 Swanson, Indulgences, 64-72.

47 Robert W. Shaffern, 'The Pardoner's Promises: Preaching and Policing Indulgences in the Fourteenth-Century English Church', The Historian 68 (2006), 49-65; Swanson, Indulgences, 278-348.

48 Swanson, Indulgences, 350-1, 522.

49 Nicole R. Rice, Lay Piety and Religious Discipline in Middle English Literature (Cambridge, 2008), xii, 7 (italics mine); Rawcliffe, Medicine, 106-7; Sheila Sweetinburgh, The Hospital in Medieval England: Gift-Giving and the Spiritual Economy (Dublin, 2004).

50 Rice, Lay Piety, xii, 7. On the forms of 'spiritual capital' (embodied, objectified and institutionalized), see Bradford Verter, 'Spiritual Capital: Theorizing Religion with Bourdieu against Bourdieu', Sociological Theory 21 (2003), 150-74, at 159-60. 
heritage and active charitable work, but also as conduits of spiritual deliverance.

The English Trinitarian province was certainly attending to the maintenance and development of its own 'spiritual capital' in the late fourteenth and fifteenth centuries, as suggested by patterns of book ownership. There are no extant Trinitarian library catalogues from medieval England, but a late fourteenth-century copy of the Middle English spiritual guidance poem Speculum vitae, attributed to William of Nassington, survives from Knaresborough and is signed by John Kylyngwyke, minister of the house from c.1380 to $1400.5^{51}$ Moreover, there was, at the Trinitarian house in Hounslow, an early printed copy of Michael Francisci's Quodlibet de veritate fraternitatis rosarii (An Academic Disputation on the True Character of the Brotherhood of the Rosary), published in 1480, which belonged first to brother John $\mathrm{Sa}[\mathrm{n}] \mathrm{dys}(?)$ of Hounslow, and then his colleague Ralph Beckwyth. ${ }^{52}$ This text promoted the Rosary prayer, an elaborate series of meditations on Mary's joys and sorrows featuring Paternosters and Aves, said to have been received direct from the Virgin by St Dominic and promoted by his followers. ${ }^{53}$ Meanwhile, among the Trinitarians at Mottenden in Kent, minister Richard Lancing possessed a manuscript containing several texts by the noted Parisian theologian Jean Gerson (1363-1429), including an affective tract entitled De oratione et valore eius (On Prayer and its Value), which draws meditative parallels between prayer and pilgrimage. ${ }^{54}$ Indeed, this last book may well have been sent to Mottenden from Knaresborough. ${ }^{55}$ Knaresborough Priory thus

51 Oxford, Bodleian Library, MS Eng. Poet. d.5. The scribal identification is noted in Richard Sharpe and James Willoughby, eds, Medieval Libraries of Great Britain, online at: <http://mlgb3.bodleian.ox.ac.uk>, accessed 31 July 2020.

52 Richmond, VA, Library of Virginia, BX890.G3, listed in Sharpe and Willoughby, Medieval Libraries.

53 Anne Winston-Allen, Stories of the Rose: The Making of the Rosary in the Middle Ages (University Park, PA, 1997), 65-8.

54 Gouda, Stichting Openbare Bibliotheek, no shelfmark. This text was held in high esteem by Thomas More: see More, De tristitia Christi, 1: The Valencia Manuscript: Facsimiles, Transcription, and Translation, ed. and trans. Clarence H. Miller, CWTM 14/1 (New Haven, CT, 1976), 765.

55 Library of Virginia, MS BX890.G3, 78. The book contains a late fifteenth-century inscription indicating that it was gifted to Richard Lancing by one Robert Bolton, 'magistri domus de'. According to Sharpe and Willoughby, Medieval Libraries, the remainder of the sentence is illegible and the house remains unidentified. We know, however, that a Robert Bolton was minister of Knaresborough from at least 1461 until as late as 1494 , so 
seems to have existed within a network of houses with demonstrable enthusiasm for the types of meditative devotion and affective literature in vogue during the late fourteenth and fifteenth centuries.

The Egerton manuscript, moreover, contains original Trinitarian prayers designed to promote meditative reflection on Robert's holy life. Thus folio 11 features an alliterative Latin verse text entitled 'The five joys of St Robert', which is immediately followed by an extensive 'Fifteen joys of St Robert'. ${ }^{56}$ Enumerating, meditating on, and sharing in the spiritual joys of a holy individual, usually key moments from their life, is a form of Marian devotion that enjoyed circulation in England in the form of Middle English lyrics. ${ }^{57}$ While these Marian-esque prayers to Robert are nowhere near as complex as those circulating in texts such as Francisci's Rosary, they do suggest an increased interest at Knaresborough in contemplative meditation as a legitimate Trinitarian activity. ${ }^{58}$ Robert is even honoured in the Egerton manuscript with a set of hours; here, both the collect, which traditionally summarizes the central theme of the day's liturgy and was repeated throughout the day, and the prayer at the most solemn hour of vespers, are suggestive of the spiritual interests and ambitions of this Trinitarian house. The collect reads:

We pray, almighty God, that you might pour the heat of your charity (calorem caritatis) into our minds, and that by intercession of your saint Robert, your confessor, we might become deserving to taste the

there is a strong chance that he is the magister to whom the inscription refers. Bolton seems to have been Lancing's predecessor as English provincial. Bolton is also styled minister of Thelsford in letters up to 1474 , and one letter of 1465 refers to him as minister of both Thelsford and Knaresborough. Lancing's ministerial career does not appear to have taken off until the 1480s, by which time one Roger Lyntton had taken over from Bolton as minister of Thelsford. Bolton continues to be styled minister of Knaresborough up to 1494: David M. Smith, ed., Heads of Religious Houses: England and Wales, 3: 1377-1540 (Cambridge, 2008), 609-15.

56 Quinque gaudia beati Roberti, London, BL, MS Egerton 3143, fols 11r-v; Quindecim gaudia beati Roberte, ibid., fols $11 \mathrm{v}-12 \mathrm{v}$.

$\$ 7$ Karen Saupe, ed., Middle English Marian Lyrics (Kalamazoo, MI, 1998). For Latin forms of the devotion, linked to further universal (predominantly female) saints, see BL, MS Sloane 2471.

58 Claire Macht has drawn parallel conclusions in the context of her study of historical writing in late medieval England. I thank Claire for sharing with me sections of her recently defended thesis, 'The Changing Nature of Monastic Historical Writing in Late Medieval England' (PhD thesis, University of Oxford, 2020). 
sweetness of your love (dulcorem dilectionis) in heaven, which he [Robert] desired with all the longing of his heart to grasp in the wilderness. 59

Then, at vespers, the text instructs the speaker to pray: 'Give me the power, $\mathrm{O}$ flower of hermits, to avoid sin at the hour of Vespers. Cure sicknesses of the flesh and of souls, offering to me the bright fire of love (amoris incendium clarum).' 60

Alongside the conspicuous pun on Robert's surname (Flower), there are parallels between the vocabulary used here and the writings of fourteenth-century Yorkshire hermit Richard Rolle (c.1300-49), who wrote in his widely read Incendium Amoris about his experience of God's love, which he first felt in the wilderness through mystical encounters with heat (calor), sweetness (dulcor) and song (canor). ${ }^{61}$ Moreover, a prayer worded very similarly to the collect can be found in one of the manuscripts of Rolle's Officium. ${ }^{62}$ There are no Rollean texts listed among the books extant from English Trinitarian libraries, but certain fifteenth-century Trinitarian brothers may have had access to this literature through their membership of York's Corpus Christi Guild. ${ }^{63}$ We are, then, perhaps glimpsing here Knaresborough Priory's creative engagement with Rollean

59 'Mentibus nostris quesumus omnipotens deus calorem tue caritatis infunde et intercessione beati Roberti confessoris tui dulcorem tue dilectionis in celis mereamur degustare: quem toto cordis desiderio comprehendere in herimo concupivit': Matutine de sancto Roberto ex devocionem dicende, BL, MS Egerton 3143, fols 10v-11r, at fol. 10v (translation, including expansion of abbreviations, and transcription mine, including 'mereamur' for MS 'meriamur').

60 'Opem michi porrege, flos herimitarum, / Ad vitanda vicia hora vesperarum. / Carni ac contagia cura animarum, / Amoris incendium prebens michi clarum’: ibid., fol. 11r (transcription, including expansion of abbreviations, and translation mine).

61 Richard Rolle, The Incendium Amoris of Richard Rolle of Hampole, ed. Margaret Deanesly (New York, 1915).

62 Uppsala, UL, MS Uppsala C. 621, fol. 103v (a fragment of the Officium), transcribed as an appendix in Harald Lindkvist, ed., 'Richard Rolle's "Meditatio de Passione Domini" according to MS. Uppsala C. 494', in Skrifter ut-gifna af Kungl. Humanistika Vctenskaps 19 (Uppsala, 1917), 73-8, at 78.

63 Eleven Knaresborough Trinitarians are recorded as guild members, with clusters of registrations in the 1430s and 1460s: see The Register of the Guild of Corpus Christi in the City of York, ed. R. H. Skaife, Surtees Society 57 (Durham, 1872), 13, 28, 33, 34, 62, 63, 83. Carmelite friar Richard Misyn translated Rolle's Incendium Amoris into Middle English in 1435 for anchorite Margaret Heslington; both may have been guild members in 1461-2: see Johan Bergström-Allen, 'The Whitefriars' Return to Carmel', in Liz Herbert McAvoy and Mari Hughes-Edwards, eds, Anchorites, Wombs and Tombs: Intersections of Gender and Enclosure in the Middle Ages (Cardiff, 2005), 77-91. 
material during a period of increased interest in contemplative activity in the later Middle Ages. Indeed, the concluding prayer set for compline explicitly asks St Robert to instruct the speaker in eremitic contemplation, and the text concludes with the words: 'make me, I entreat (flagito), a brother to you in the struggle (tibi in agone fac me fratrem) ... so that, with contemplation of heaven, I might delight in extraordinary things here in this house (contemplacione sic ut poli perfruar mira mansione)'. ${ }^{64}$ Moreover, the intensely alliterative form of further Latin prayers in the Egerton manuscript is reminiscent of the sort of ecstatic mystical writing for which Rolle is well known. ${ }^{65}$ Knaresborough Priory thus seems to have come to associate an interest in Rollean contemplative spirituality with the spirituality it envisaged its patron saint having practised centuries before in the wilderness.

By the end of the medieval period, through their copying of spiritual guidance poetry and their composition of new devotional texts linked to Robert's cult, the Knaresborough Trinitarians seem to have increased and diversified the amount of meditative and devotional literature at their disposal. Might Robert's eremitic charisma, as textualized in Latin verse, have been designed to sustain and further inspire new literary and contemplative directions in the spiritual life of English Trinitarians in this period? This is the impression one gets from reading the history of the Trinitarian order appended to the Latin verse hagiography: while describing the order's tripartite financial structure (stanza 15) and historical redemptive purpose (stanzas 16-26) in some detail, the text also features an early petition that Trinitarian brothers might be able to explore a less active, more devotional way of life within the walls of their church: 'May the objective of this monastery be sincerely to please the Creator; and to practice in the monastery acts nourishing to the soul.' ${ }^{\prime} 6$ The next stanza references the liturgical life of the priory and its hymns and hours, and the author then describes Trinitarian brothers engaged in meditative

\footnotetext{
64 Matutine de sancto Roberto, fol. $11 \mathrm{r}$ (transcription, including expansion of abbreviations, and translation mine, including 'perfruar' for MS 'perfruer').

65 See ibid., fols $12 \mathrm{v}-14 \mathrm{r}$ (a poem about Robert made up of words beginning with ' $\mathrm{p}$ '), $14 \mathrm{r}-\mathrm{v}$ (an acrostic in which the alliteration is structured around the letters of Robert's name). On Rolle's alliteration, see Nicolas Watson, Richard Rolle and the Invention of Authority (Cambridge, 1991), 178-9.

66 'Causa celle sit scincere / Plasmatori complacere, / Et in cella exercere / Almos actus anime': De innovatione, stanza 2.
} 
practice: 'The brothers bear the cross of Christ for meditating with contrite heart on the Redeemer, through whom they have been saved by [his] blood.' ${ }^{67}$ The text then goes on to describe the Trinitarian habit (stanzas 6-14) and introduces the legend that the order was founded by two hermits who went to Rome and received papal approval for their redemptive project (stanzas 32-8). ${ }^{68}$ Prior to this, De innovatione had celebrated the Trinitarian order in superlative terms as a model of fraternity: 'The Order of the Holy Trinity is the flower of brotherhood, which like the sun of serenity will shine forth to the brothers.' 69

In epitomizing Trinitarian eremitism as 'the flower of brotherhood', De innovatione calls to mind the life of the hermit Robert Flower, who, as seen above, is addressed elsewhere in the Egerton manuscript as 'flower of hermits'. ${ }^{70}$ Indeed, the juxtaposition of the Latin verse life of Robert with a complementary history of the legendary, anonymous but decidedly eremitic roots of the Trinitarian order writes Robert into Trinitarian history and simultaneously imbues that history with the exemplary eremitic values espoused in the attached hagiography. In what sense, however, could Robert's individualistic, prayerful eremitism, rather than his active charity and communitymindedness, be celebrated as a quasi-foundational tenet of Trinitarian life?

The answer, perhaps, lies in changing notions of Trinitarian redemption during the late medieval period. As Brodman has observed, Trinitarian ransom work was in decline in the fourteenth and fifteenth centuries, and 'the Trinitarians of England and Scotland display the same lack of interest in the liberation of captives as we have encountered in northern France'. ${ }^{71}$ This reading corresponds well to the fact that during the early fifteenth century the English province appeared resistant to paying a third of its income towards the redemption of captives, claiming instead that the English houses were accustomed to payment of a ransoming quota smaller than the 'third part' mandated by their order's Rule. On

\footnotetext{
67 'Fratres ferunt crucem Cristi, / Meditando mente tristi / Redemptorem, per quem isti / Sunt salvati sanguine': ibid., stanza 5.

68 Brodman, 'Trinitarian and Mercedarian Orders', 132-46.

69 'Ordo Sancte Trinitatis / Flos est fraternitatis, / Qui ut sol serenitatis / Prefulgebit fratribus': De innovatione, stanza 27.

${ }^{70}$ See n. 60 above.

71 Brodman, Charity and Religion, 162.
} 
the other hand, De innovatione describes Christian captivity in the Holy Land (stanzas 18-21) and Trinitarian ransoming activity (stanzas 39-40) in some detail, reinforcing the expectation that all Trinitarian brethren should be committed to the redemption of captives: 'If all who are professed Trinitarians do not take account of this obligation of the cross, they will end in the devil's house. ${ }^{72}$ This suggests that the English brethren were not as straightforwardly uninterested in redemptive activity as Brodman implies. Moreover, and contrary to Brodman's assertion that the Trinitarians refused 'here as elsewhere to broaden the definition of captivity beyond those held in Muslim lands', Jan Luc Liez has argued convincingly for an increasingly metaphorical interpretation of captivity and ransom among the Trinitarians, for whom redemptive activity, he argues, probably came to encompass the liberation of souls. ${ }^{73}$ At one point De innovatione suggests that the order facilitates the rescue of sinners. ${ }^{74}$ I wish to complement Liez's argument, then, by proposing that the centralization of Robert's prayerful eremitism in De nobilitate (combined with, and partly constituted by, the same text's de-emphasis of that hermit's famed poor relief), was a conscious literary strategy designed to inspire later medieval Knaresborough Trinitarians to pray and meditate on Robert's life and in his image. This would enable the order to accrue sufficient spiritual capital to facilitate a wider Trinitarian goal of liberating sinful Christians from purgatorial suffering.

If this holds, then the Latin verse pairing speaks to a much altered institutional vision of Trinitarian life in England at the end of the medieval period, which recognized that English Trinitarian brethren were no longer so closely aligned to active redemptive work as they once might have been, and reflected the new literary, contemplative and spiritual interests that the Trinitarians were developing at the turn of the fifteenth century. This is not to say that the Trinitarians of later medieval England had necessarily become

\footnotetext{
72 'Huic omnes obligati / Sunt professi Trinitati; / Si non curent cruciati, / Erunt domo demonis': De innovatione, stanza 41.

73 Brodman, 'Trinitarian and Mercedarian Orders', 239; Jan Luc Liez, 'L'Esclavage comme métaphore religieuse dans l'iconographie de l'ordre des Trinitaires', in Elizabeth McGrath and Jean-Michel Massing, eds, The Slave in European Art: From Renaissance Trophy to Abolitionist Emblem (London and Turin, 2012), 63-81.

74 'Ordo sanus est inceptus / Per quem reus est ereptus' ('A healthy order has been started, by means of which the guilty [person] has been rescued'): De innovatione, stanza 31.
} 
detached from their commitment to local charity or physical care. Rather, it is to highlight that the province had developed concomitant spiritual and contemplative interests alongside its traditional institutional focus on redemptive and corporal works of mercy, in a period when English ties to traditional Trinitarian ransom work had lessened. These interests coalesced with the late medieval spiritual economy and essentially revived - but also rewrote - the founding purpose of the order in such a way that it could continue to be celebrated and mandated in late medieval England.

\section{A Conflicting Model of Inspirational Sanctity? The Middle ENGLISH LIFE}

In contrast to the image of Robert presented in De nobilitate, the hermit's active charity is given particular emphasis in the near-contemporary Middle English translation of his legend, the fifth-to-last item in the Egerton manuscript. ${ }^{75}$ Written in octosyllabic couplets, this text opens in the style of a romance and is addressed to a fictional audience of (apparently noble) feasting 'frendes' (line 35), who may be synonymous with literate gentry or upper mercantile members of the Trinitarian confraternity. ${ }^{76}$ The text's narrator appears to hope to cajole his audience into parting with their 'bred' for the benefit of the poor: 'Partte a porcioun vnto the pore / Sway dyd Sayntt Robert att hys dore', perhaps a metaphorical petition for charitable donations to the Trinitarian cause. ${ }^{77}$ Here in the vernacular, however, Robert's eremitic charisma is expressed not simply according to the traditional trope of the miles Christi, but also in the language of secular heroism, such that the saint is presented in chivalric terms as a figure who outshines 'Arthure, Ector, and Achilles' (line 39). Robert is even labelled 'Cheftane and chefe of charite' (line 74) and thus his charity is presented in secular terms as something worthy of lay imitation.

\footnotetext{
75 Dated to the late fourteenth or fifteenth centuries in Bazire, ed., Metrical Life, 15.

76 Life, lines 35-46. Trinitarian confraternity letters were obtained by members of these social strata. See the list of individuals mentioned in Clark-Maxwell, 'Some further Letters', 212-13; Raluca Radulescu, 'Literature', in eadem and Alison Truelove, eds, Gentry Culture in Late Medieval England (Manchester, 2005), 100-18.

77 Life, lines 285-96 (quotation at lines 291-2); Matthew Woodcock, 'Crossovers and Afterlife', in Sarah Salih, ed., A Companion to Middle English Hagiography (Cambridge, 2006), 141-56.
} 
The Egerton manuscript thus seems to be bookended by two radically different late medieval versions of Robert's life: one in Latin verse, which minimizes Robert's care for the poor and seems to have been intended for internal consumption at Knaresborough Priory, offering a more spiritual interpretation of the Trinitarian raison d'etre; the other written in the vernacular, also in verse, and intended for circulation outside the priory, to elaborate Robert's story for a secular audience of would-be patrons who might be inspired to imitate Robert's exemplary active charity and to support the Trinitarian cause financially. While the depictions of Robert in these texts exist, ostensibly, in tension with one another, when read in the context of English Trinitarian investment in the late medieval spiritual economy they can also be considered complementary narratives, both designed to support and add spiritual value to secular engagement with St Robert's cult and his Trinitarian shrine-keepers. Despite an early Trinitarian impulse to bring Robert's life in line with order's corporate and charitable values, then, the hermit's borderline transgressive (but nevertheless inspirational) holy legacy was never bound too rigidly by his hagiographers. Indeed, Trinitarian institutionalization of Robert's charismatic authority at Knaresborough was inherently and continuously unstable, a quality that allowed the inspirational and generative force of his spirit to continue exercising itself textually during the fourteenth and fifteenth centuries, in contending yet complementary ways in both sacred and secular spheres. In sum, among the Trinitarians at Knaresborough, Robert's charisma facilitated a spiritual flourishing and a late medieval institutional reinvention of redemption that is quite at odds with narratives of English Trinitarian marginality and decline. 